\title{
UM FINAL FELIZ PARA O NARRADOR? O ROMANCE A HISTÓRIA SEM FIM COMO ALEGORIA BENJAMINIANA
}

Maya Moldes

\begin{abstract}
RESUMO
No ensaio O Narrador - considerações sobre a obra de Nicolai Leskov, Walter Benjamin faz um diagnóstico claro: a verdadeira narrativa está em vias de extinção. Dito isso, ele procura definir suas características essenciais, bem como apontar alguns dos culpados por seu declínio, como a ascensão do romance e da informação jornalística. No entanto, esse artigo busca recorrer justamente a um romance, A História sem Fim, de Michael Ende, para responder a questão não explicitada em Benjamin: como continuar contando histórias? A escolha não recaiu nesta obra literária em vão; mobilizando o conceito de alegoria benjaminiana, iremos assumir correspondência entre o ensaio e o livro, fazendo a aposta de que $A$ História sem Fimnão só é uma verdadeira narrativa, como, por reflexões possíveis a partir de seu conteúdo e forma, nos traz possibilidades de como resistir à dita extinção do narrar.
\end{abstract}

Palavras-chave: Benjamin; Ende; Narrativa; Infância; Literatura.

\section{A HAPPY FINAL FOR THE NARRATOR? THE ROMANCE THE ENDLESS HISTORY LIKE BENJAMINIAN ALEGORIA}

\begin{abstract}
In the essay The Storyteller - Reflection son the Works of Nikolai Leskov, Walter Benjamin makes a clear diagnosis: the true narrative is in the process of extinction. That said, heaims to define its essential characteristics as well as to point out some of the culprits for its decline, such as the rise of the novel and journalistic information. However, this articles east appeal precisely to a novel, The Never Ending History, by Michael Ende, to answer the question not explicit in Benjamin: how to continue telling stories? The choice of this particular history was not random; mobilizing Benjamin's concept of alegory, we will assume a correspondence between the essay and the book, making the bet that The Never Ending History is not only a true narrative, but also, through possible reflections from its content and form, it bring suspossibilities of how to resist to the extinction of narrating.
\end{abstract}

Keywords: Benjamin; Ende; Narrative; Childhood; Literature.

"O canto junto à lareira ou perto do forno de lenha na cozinha, o lugar ao pé da escada, os feriados que ainda se festejam, os pastos e as florestas em seu silêncio e, sobretudo, a fantasia - são essas as

Maya Moldes; Mestranda no Programa de Pós-Graduação em História na Universidade Federal do Estado do Rio de Janeiro (PPGH - UNIRIO); Brasileira; reside em Rio de Janeiro - RJ; email: maya.moldes.mrp@gmail.com 
cercas vivas que protegeram essas histórias e levaram a tradição de uma época à outra." (Jacob e Wilhelm Grimm).

Este artigo surgiu da familiaridade na leitura de dois textos, embora de modo algum se deva entender "familiar" como um esgotamento de sentido dos mesmos, pelo contrário. Por esse termo compreendo afeto, daquele tipo que nos torna capaz de, incansavelmente, descobrir novas qualidades em velhos conhecidos, as quais espero compartilhar com o leitor. Walter Benjamin não leu Michael Ende, cuja primeira publicação data de 1960'; talvez tenha conhecido as pinturas surrealistas de seu pai, Edgar Ende, dado o interesse pelo tema. $\mathrm{Na}$ biografia de Ende que foi possível encontrar, tampouco há registros de uma leitura de Benjamin. A vontade de apresentar ambos, que, creio, tem muito que dialogar, é o que guia o artigo. Esse diálogo concerne à questão das narrativas tradicionais e seu declínio, bem como possíveis desvios - para usar uma expressão benjaminiana - desse certeiro ocaso.

Para tanto, o texto será dividido em mais três partes. A saber, a primeira que busca corresponder $A$ História sem Fim a uma verdadeira narrativa ${ }^{2}$ (BENJAMIN, 2012, 2116), através (e não apesar) das suas particularidades enquanto romance; a segunda, guiada pelo conceito de alegoria, que irá tratar do teor em comum às duas obras; finalmente a terceira, na qual tentaremos propor o final feliz que Benjamin não oferece, mas Ende sim, elaborando possibilidades às questões levantadas por ambos nas fontes escolhidas.

Die Unendliche Geschichte, escrito pelo famoso autor de livros infantis Michael Ende,é publicado em 1979. Em 1984 foi adaptado para o cinema com roteiro do próprio Ende e direção de Wolfgan, g Petersen, o que talvez seja a lembrança que vêm à cabeça de muitos, ao mencionarmos o título desta história,

\footnotetext{
1 Trata-se do livro Jim KnopfundLukas der Lokomotivführer.

2 Essa expressão aparece uma vez ao longo do ensaio, mas será adotada no artigo de forma corrente. Como a palavra "narrativa" é de senso comum em nosso vocabulário e não corresponde necessariamente às tradicionais descritas por Benjamin, creio ser válida a distinção. Inclusive há uma tradução recente para o termo "contador de histórias", feita por Georg Otte, Marcelo Backes e PatriciaLavelle, no livro A Arte de Contar Histórias, o primeiro volume da Coleção Walter Benjamin da Editora Hedra.

Maya Moldes; Mestranda no Programa de Pós-Graduação em História na Universidade Federal do Estado do Rio de Janeiro (PPGH - UNIRIO); Brasileira; reside em Rio de Janeiro - RJ; email: maya.moldes.mrp@gmail.com
} 
especialmente as maravilhosas cenas de voo no dragão da sorte Fuchur. A edição que nos utilizamos data de 1986, feita por Maria do Carmo Cary e publicada pela Martins Fontes.

Assumindo que nem todos estão a par de seu conteúdo, sendo este de indispensável relevância para a compreensão dos pontos que serão levantados, irei apresentar o livro brevemente. A obra se divide em duas histórias, que hora e outra se chocam, até finalmente coincidirem. Trata-se de duas dimensões: 0 mundo real, verossímil ao que conhecemos, protagonizado pelo menino gorducho, tímido e solitário, chamado Bastian e o mundo fantástico (nomeado inclusive de Fantasia), protagonizado pelo esbelto, destemido e solitário menino Atreiú. Certo dia, ao fugir da perseguição praticada por seus colegas de escola, Bastian entra em um sebo, donde um exemplar em especial the chama atenção: ora, não é outro senão $A$ História sem Fim! Aproveitando-se de uma distração do dono (que mais tarde saberemos ser proposital, para garantir o desenrolar dos acontecimentos), Bastian obedece ao súbito impulso de se apoderar do volume e sair correndo, indo se acomodar no sótão de sua escola, onde começa a ler as aventuras que se passam em Fantasia. Escrito em duas cores de fonte (vinho para o real e verde para o fantástico), alternamo-nos entre a criança que cabula aula e a história que ele mesmo lê e o envolve, à medida que vira as páginas, até finalmente entrar nelas, tornando-se duplamente personagem e percorrendo um longo caminho até retornar a sua casa.

Com essas informações, creio que podemos dar início à prometida demonstração de A História sem Fim como uma verdadeira narrativa. Para tanto, é preciso definir esse tipo a partir do ensaio de Benjamin:

\footnotetext{
A narrativa, que durante tanto tempo floresceu num meio artesão - no campo, no mar e na cidade - é ela própria, num certo sentido, uma forma artesanal de comunicação. Ela não está interessada em transmitir "o puro em si" da coisa narrada, como uma informação ou um relatório. Ela mergulha a coisa na vida do narrador para em seguida retirá-la dele. Assim, imprime-se na narrativa a marca do narrador, como a mão do oleiro na argila do vaso. (BENJAMIN, 2012, 221).
}

Na última capa de $A$ História sem Fim há a seguinte inscrição:"Fantasia é a história sem fim escrita num livro de capa cor-de-cobre que estava no sótão de um colégio. Agora, ele está na sua mão”. (ENDE, M.). O que podemos destacar 
nos dois trechos é a figura da mão. No segundo, ela poderia passa rdespercebida; o livro é um objeto físico, obviamente, é preciso segurá-lo em mãos. No entanto, esconde-se aí um convite: se analisarmos o trecho, veremos que ele nos conta uma breve história do objeto. Ele veio especialmente de um lugar, o sótão de um colégio, e, agora, encontra-se não em outra, mas na sua mão ${ }^{3}$. Dessa forma, começa a se criar uma aura de magia e subjetividade, pois, retomando os trechos acima, se a narrativa é coisa distinta do narrador, embora indissociáveis ambos, por sua natureza artesanal, que só pode se realizar junta, assim também o é o romance de Ende; poderíamos traduzir a citação da última capa pela seguinte: "bem-vindo a esta matéria prima; por ora, ela lhe pertence, deixe-Ihe a sua marca". O leitor de Benjamin sabe que ele se refere a narrativas orais, o que breve será abordado. O objeto livro, por mais que neste caso haja o convite para encará-lo como mágico, não possui a natureza maleável da argila, pois está impresso. Como resolver essa questão? Benjamin diz:

Com efeito, não há em nenhuma narrativa em que a pergunta - e o que aconteceu depois? - não se justifique. O romance, ao contrário, não pode dar um único passo além daquele limite em que, escrevendo na parte inferior da página a palavra fim, convida o leitor a refletir sobre 0 sentido de uma vida. (BENJAMIN, 2012, 230).

A História sem Fim. Suas 392 páginas parecem aquém da promessa contida no título, mas há no interior da obra uma estratégia que garante sua realização. Há muitas personagens no livro, muitas tramas levantadas que não contribuem com o desenrolar do enredo principal. Fosse o último capítulo de uma novela, todas seriam brevemente mencionadas e resolvidas, ganhariam o seu fim, mas Ende não se preocupa com isso. Ele as resolve não resolvendo, ao lançar mãoda seguinte frase, com a qual encerra todos os seus pontos sem nó: "Mas esta é uma outra história e será contada em outra ocasião." Ocasião que nunca se apresenta, a não ser é claro, que o leitor deixe a cargo de sua imaginação.

Complementando com as palavras de Jeanne Marie Gagnebin, filósofa referência nos estudos sobre Walter Benjamin:

\footnotetext{
${ }^{3}$ Para maiores informações sobre a presença da mão, sugiro o interessante ensaio Elogio da mão, escrito por Henri Focillon, publicado pelo Instituto Moreira Salles (Clássicos serrote), edição de 2012.

Maya Moldes; Mestranda no Programa de Pós-Graduação em História na Universidade Federal do Estado do Rio de Janeiro (PPGH - UNIRIO); Brasileira; reside em Rio de Janeiro - RJ; email: maya.moldes.mrp@gmail.com
} 
Essa dimensão, que me parece fundamental na obra de Benjamin, é a da abertura. O leitor atento descobrirá em "O Narrador" uma teoria antecipada da obra aberta. (...) O que me importa aqui é identificar esse movimento de abertura na própria estrutura da narrativa tradicional. Movimento interno, representado na figura de Sherazade, movimento infinito da memória, notadamente popular. (...) Cada história é o ensejo de uma nova história, que desencadeia uma outra, que traz uma quarta etc.; essa dinâmica ilimitada da memória é a da constituição do relato, com cada texto chamando e suscitando outros textos. (apud. BENJAMIN, 2012,12,13).

E se não há fim, também não há o convite a se refletir "sobre o sentido de uma vida". Possui, ao invés disso, uma pretensão mais humilde, que tomaremos como valiosa: a capacidade de dar conselhos. Ora, se esses são possíveis apenas a partir de uma forma de experiência que não existe mais ${ }^{4}$, como o livro poderia transmiti-los? Benjamin diz: “(..) entre as narrativas escritas, as melhores são as que menos se distinguem das histórias orais contadas pelos inúmeros narradores anônimos". (BENJAMIN, 2012, 214). E completa: "O primeiro narrador verdadeiro é e continua sendo o narrador dos contos de fadas. Esse conto sabia dar um bom conselho, quando ele era difícil de obter, e oferecer sua ajuda, em caso de emergência." (BENJAMIN, 2012, 232). Fantasia não passa de um apanhado de contos-de-fadas. Há sábios centauros, dissimuladas feiticeiras, valorosos heróis, tolos gigantes, ambiciosas raposas e mesmo uma velha e prudente tartaruga, que não possui nenhuma pressa. E não só $A$ História sem Fim é uma verdadeira narrativa, como Bastian é um verdadeiro narrador. Como veremos na terceira parte, é justamente um bom conselho seu, que intervém no "caso de emergência".

Se ainda restam dúvidas sobre a correspondência entre o romance e a forma de narrar descrita no ensaio, por esta pertencer a uma época já longínqua (que Benjamin nunca se preocupou em precisar historicamente), vamos mencionar um traço de sua natureza: "Ela assemelha-se as sementes de trigo que durante milhares de anos ficaram fechadas hermeticamente nas câmaras

\footnotetext{
${ }^{4}$ Novamente recorrendo à professora Gagnebin: "Essa experiência está ligada a uma tradição viva e coletiva, característica das comunidades em que os indivíduos não estão separados pela divisão capitalista do trabalho, mas onde sua organização coletiva reforça a vinculação consciente a um passado comum, permanentemente vivo nos relatos dos narradores. Nessas comunidades pré-capitalistas - que não são por isso forçosamente idílicas! - a experiência do trabalho e do passado coletivos (Erfahrung, no vocabulário de Benjamin) predomina sobre a experiência do indivíduo, isolado em seu trabalho e sua história pessoal (Erlebnis)." (GAGNEBIN, 1993:58, 59).

Maya Moldes; Mestranda no Programa de Pós-Graduação em História na Universidade Federal do Estado do Rio de Janeiro (PPGH - UNIRIO); Brasileira; reside em Rio de Janeiro - RJ; email: maya.moldes.mrp@gmail.com
} 
das pirâmides, conservando até hoje suas forças germinativas." (BENJAMIN, 2012, 220). Por que não assumir que germinaram em Ende?

II

Para desenvolver a prometida correspondência entre o teor de nossas duas obras é necessário lançar mão do conceito de alegoria, cujo sentido etimológico é possível traduzir como "dizer o outro", que Benjamin trabalhou em seu livro Origens do drama trágico alemão5: "Ora, a alegoria (...) não é uma retórica ilustrativa através da imagem, mas expressão, como a linguagem e também a escrita." (BENJAMIN, 2016, 173). A partir dessa definição é possível fazer uma ressalva importante. Aproximar os conteúdos de A História sem Fim e O Narrador, não é considerar o primeiro como ilustração literária dos dizeres filosóficos do segundo, tal um espelho de diferente linguagem, nem dizer que há algo de inato na semelhança entre ambos. Nossa intenção é fazer essa aproximação de forma consciente, considerando a diferença na linguagem não como possível de tradução literal, mas distinção determinante no que cada obra pode expressar. Justamente por essa carência de reflexo é que faz sentido e vale a pena o estudo dos dois textos juntos. Porque não buscamos confirmação de um no outro, mas abertura de possibilidades.

O contraponto da alegoria com o símbolo nos ajuda a entender melhor seu principio. O primeiro é “(...) a indissociabilidade de forma e conteúdo” (BENJAMIN, 2016, 170). Representa a totalidade, a plenitude e está ligado, ao menos no capítulo de Benjamin, a uma estética romântica. A alegoria, por sua vez, é a não correspondência, a não simetria, a não representação plena: "Símbolo e alegoria estão um para o outro como o grande, mudo e poderoso mundo natural da montanha e das plantas para a história humana, viva e em

\footnotetext{
${ }^{5}$ Bernd Witte, presidente da Sociedade Internacional Walter Benjamin (IWBG), na excelente biografia que lançou sobre o autor (tradução de Romero Freitas, publicada pela Autêntica, 2017), diz o seguinte sobre a mais famosa obra benjaminiana: "A história do surgimento do livro sobre o drama trágico deixa claro que se trata de uma obra-limite. Por um lado, suas intenções ainda são essencialmente conservadoras, na medida em que se dedica ao comentário de uma forma histórica da literatura alemã. Por outro lado, através da sua destruição da estética do símbolo, bem como de sua crítica radical da ciência e de sua imagem pessimista da história, presta contas das experiências políticas que seu autor teve na época de sua elaboração: conclusão do ciclo de produção "germanística", como Benjamin constata em uma carta a Scholem, mas também esboço de uma estética pós-simbólica, que se sabe em concordância com as forças históricas mais profundas de seu tempo." (WITTE, 2017, 61, 62).

Maya Moldes; Mestranda no Programa de Pós-Graduação em História na Universidade Federal do Estado do Rio de Janeiro (PPGH - UNIRIO); Brasileira; reside em Rio de Janeiro - RJ; email: maya.moldes.mrp@gmail.com
} 
contínua progressão." (BENJAMIN, 2016, 176). Esclarecida essa definição, podemos dar início à análise das fontes.

Foi dito que o que há em comum em ambas é o declínio da narrativa. Em O Narrador, esse tema permeia todas as páginas. Ironicamente, se não uma das causas, ao menos um dos sinais de sua decadência, é o surgimento do romance: "O primeiro indício que vai culminar no ocaso da narrativa é o surgimento do romance no período moderno." (BENJAMIN, 2012, 217). Porque o romance está, essencialmente,vinculado ao livro, "nem precede da tradição oral, nem a alimenta" (BENJAMIN, 2012, 217) e tanto seu autor quanto o leitor, estão sós. Em Ende, o tema é igualmente apresentado desde o início. Logo nas primeiras páginas lidas por Bastian, ficamos sabendo que o reino de Fantasia se encontra gravemente doente, assim como aquela que o rege, a imperatriz Criança. Ninguém sabe a causa desse mal, tampouco pode apontar seu surgimento; quando deram por si, já estavam acometidos de tamanha desgraça. A primeira cena descreve um grupo de mensageiros das mais diversas partes dessa terra sem fronteiras, reunidos em uma clareira e descobrindo que portam uma urgência em comum, isto é: chegar ao centro de Fantasia, à Torre de Marfim, onde reside a imperatriz e pedir conselho sobre como lidar com o mal que se abateu sobre suas respectivas terras. É descrito da seguinte forma:

- Na nossa terra, no Pântano da Podridão, continuou o fogo-fátuo, hesitante, aconteceu uma coisa... uma coisa inacreditável... Ou melhor, ainda está para acontecer... é difícil explicar... começou assim: a leste da nossa terra há um lago... ou melhor dizendo, havia... que se chamava Caldo Fervente. Tudo começou quando, certo dia, o lago Caldo Fervente desapareceu... pela manhã, não estava mais ali. Compreendem?

- Quer dizer que secou?, perguntou Ukuk.

- Não, respondeu o fogo-fátuo. Se assim fosse, haveria ali um lago seco. Mas não foi assim. No lugar onde havia o lago não havia nada... nada mesmo, compreendem?

- Havia um buraco?, rangeu o comedor de rochedos.

- Não, não havia um buraco. O fogo-fátuo parecia cada vez mais atrapalhado. Um buraco ainda é alguma coisa. E ali não há nada. (ENDE, 1986,19).

"E ali não há nada." O nada está consumindo Fantasia, o reino das histórias de fadas, das criaturas imemoriais, que encantam ou assombram as 
crianças há gerações. A própria infância, representada pela imperatriz, se encontra grave e indissociavelmente doente. A Atreiú é confiada a tarefa de descobrir a causa e a cura deste mal:

Ela manda que você procure no desconhecido uma coisa que ninguém sabe o que é.Ninguém pode lhe ajudar, ninguém pode lhe aconselhar, ninguém pode prever o que você vai encontrar. Apesar disso, porém, é preciso que você decida imediatamente, aqui e agora, se aceita ou não essa missão.

$(\ldots)$

- Em que consiste essa missão?, quis saber Atreiú.

- Em encontrar o remédio para a imperatriz Criança e salvar Fantasia, respondeu o velho centauro.

$(\ldots)$

Atreiú levantou a cabeça e olhou-o.

- Aceito, disse com firmeza. (ENDE, 1986, 37- 38).

A partir de então, nosso herói se lança nessa jornada sem fim, mas não está só. A cada aventura, a cada perigo ou emoção, Bastian se encontra mais próximo dele, mais dentro da história, assim como nós 6 .

Em seguida há outro trecho que melhor descreve o nada:

As copas das árvores mais próximas eram verdes, mas a folhagem das árvores afastadas parecia ter perdido a cor, era cinzenta. Um pouco mais adiante, tornava-se estranhamente transparente, nebulosa, ou melhor, parecia cada vez mais irreal. E para além dessas árvores não havia nada, absolutamente nada. Não era um lugar ermo, nem uma zona escura ou clara; era algo insuportável à vista e que dava às pessoas sensação de terem ficado cegas. Pois não há olhos que suportem olhar o nada total. (ENDE, 1986:49).

Podemos também dizer que essa é uma "paisagem em que nada permanecera inalterado, exceto as nuvens, e, debaixo delas, num campo de forças de torrentes e explosões destruidoras, o frágil e minúsculo corpo humano". (BENJAMIN, 2012, 214). Em Benjamin, essa passagem diz respeito à experiência da Primeira Guerra. É difícil associar um cenário destruído pela violência com o nada, afinal, há tantos corpos e tantos escombros... Mas se retomarmos o início do parágrafo, de onde o excerto foi extraído, temos: "Não se

\footnotetext{
${ }^{6}$ Sobre o envolvimento de um leitor com o livro, sugiro a leitura de Seis passeios pelos bosques da ficção, de Umberto Eco, com especial atenção aos conceitos de leitor-empírico e leitormodelo.

Maya Moldes; Mestranda no Programa de Pós-Graduação em História na Universidade Federal do Estado do Rio de Janeiro (PPGH - UNIRIO); Brasileira; reside em Rio de Janeiro - RJ; email: maya.moldes.mrp@gmail.com
} 
notou, ao final da guerra, que os combatentes voltavam mudos do campo de batalha; não mais ricos, e sim mais pobres em experiência comunicável? (BENJAMIN, 2012, 214). Essa pobreza de experiência não pode ser tomada pelo nada? E a diferença nas paisagens - o caos no mundo real, o vazio no mundo fantástico - se explica porque em Fantasia esse fenômeno de esvaziamento toma dimensão literal.

Tornando a Walter Benjamin:

É a experiência de que a arte de narrar está em vias de extinção. São cada vez mais raras as pessoas que sabem narrar devidamente. É cada vez mais frequente que, quando o desejo de ouvir uma história é manifestado, o embaraço se generalize. É como se estivéssemos sendo privados de uma faculdade que nos parecia totalmente segura e inalienável: a faculdade de intercambiar experiências. (BENJAMIN, 2012, 213).

Ou seja, assim como a doença atinge a imperatriz e o reino, também em Benjamin vemos uma dupla consequência desse esgotamento: na figura do narrador e nas narrativas. Em seu ensaio, fatores são apontados mais como indícios do que como causas. Ende não possui semelhante reserva; iremos analisar a passagem em que consta o diagnóstico dessa doença:

- Você vive pouco, menino. Nós vivemos muito 7 . Vivemos demais. Mas ambos vivemos no tempo. Você pouco tempo, eu muito. A imperatriz Criança já existia antes de nós. Mas não é velha. É sempre jovem. Repare. A vida dela não se mede em tempo, mas sim em nomes. Precisa de um nome novo, precisa sempre de ter um novo nome. Sabe os nomes dela, menino?

- Não, reconheceu Atreiú. Nunca os ouvi.

- Porque não pode tê-los ouvido, explicou Morla. Nem sequer nós somos capazes de nos lembrar desses nomes. E, no entanto, teve muitos. Mas todos foram esquecidos. Todos passaram. Sem um nome, porém, ela não pode viver. A imperatriz Criança precisa apenas de um novo nome para ficar curada. Porém, tanto faz que se cure ou não ${ }^{8}$. (ENDE, 1986, 55).

\footnotetext{
7 Trata-se da velha Morla, a tartaruga; por viver sozinha há muito e conversar somente consigo mesma, adotou o hábito da primeira pessoa do plural.

8 Creio ser interessante comentar que é justo em uma anciã que o livro anuncia suas respostas. Em O Narrador. "Ora, é no moribundo que não apenas o saber e a sabedoria do homem, mas sobretudo sua vida vivida - e é dessa substância que são feitas as histórias - assumem pela primeira vez uma forma transmissível. Assim como no interior do agonizante desfilam inúmeras imagens - visões de si mesmo, nas quais ele havia se encontrado sem dar-se conta disso -, o inesquecível aflora de repente também em suas expressões e olhares, conferindo a tudo que the dizia respeito aquela autoridade que mesmo um pobre-diabo possui, ao morrer, para os vivos ao seu redor. Na origem da narrativa está essa autoridade. (BENJAMIN, 2012, 224). E é dessa Maya Moldes; Mestranda no Programa de Pós-Graduação em História na Universidade Federal do Estado do Rio de Janeiro (PPGH - UNIRIO); Brasileira; reside em Rio de Janeiro - RJ; email: maya.moldes.mrp@gmail.com
} 
Temos aí: a imperatriz, de cuja saúde depende todo reino, precisa apenas de um novo nome para ficar curada. Ora, segundo seu procedimento crítico, Benjamin distingue a linguagem em quatro níveis, sendo uma delas que vale a pena mencionar, a adâmica: “(...) que é uma linguagem do puro conhecimento no ato de nomear." (WITTE, 2017,32). Complementando com Witte:

Ela é, por um lado, significativa; por outro lado, é a expressão de uma essência espiritual que apenas nela se comunica. Na medida em que traduz em palavras a linguagem muda das coisas, mas na medida em que nela também se exprime a essência espiritual do falante, ela é ao mesmo tempo conceptividade e espontaneidade. (WITTE, 2017, 33).

A imperatriz precisa receber o nome certo. Essa certeza, no entanto, não se dá por alguma espécie de revelação, apesar de que esta dimensão não pode ser totalmente excluída; ela também precisa exprimir "a essência intelectual do falante", que, no caso, é Bastian. Isso significa que a imperatriz Criança tem um nome único para cada homem ou mulher que a nomeia, mas esse nome também é a tradução da linguagem muda do que ela é. Bastian realiza essa tarefa percorrendo a história e somente através desse percurso, não de um ato contemplativo, que o nome se revela: "E no mesmo instante soube também o seu nome: Filha da Lua. Não havia a menor dúvida de que era esse o seu nome." (ENDE, 1986, 148).

Prosseguindo com Ende, há mais um personagem que reforça e complementa os avisos da velha Morla. O oráculo do sul, Uiulala, que nosso amigo Atreiú possui especial dificuldade em alcançar:

"Responde, Uiulala, quem a poderá salvar? Quem poderá saber que novo nome the dar?"

Durante um momento, ouviu-se apenas um som plangente, sem palavras, mas logo a voz voltou a soar muito perto de Atreiú, como se Ihe falasse ao ouvido:

Quem dará um nome novo,

À Criança imperatriz?

Nem tu, nem eu, nem elfo, nem ogro.

Poderá alguém salvar-lhe? Diz!

autoridade que Morla deriva seus conselhos, não de uma habilidade extraordinária de adivinhação, como seria razoável esperar das personagens desse gênero de livro.

Maya Moldes; Mestranda no Programa de Pós-Graduação em História na Universidade Federal do Estado do Rio de Janeiro (PPGH - UNIRIO); Brasileira; reside em Rio de Janeiro - RJ; email: maya.moldes.mrp@gmail.com 
Livrar-nos do mal ninguém pode.

Nem tampouco a podemos curar.

Somos apenas personagens de um livro

E cumprimos o que o autor destinar.

Da história figura e sonho

É tudo o que somos, o que de ser precisamos.

Não podemos, portanto, criar algo novo

Sábio, Criança ou Rei que sejamos.

Mas do outro lado, além de Fantasia,

Existe um reino, o mundo exterior,

De grande riqueza, de um povo moradia,

Que de outra missão é cumpridor.

Os filhos de Adão, justo é o nome,

Dos habitantes do mundo da Terra.

As filhas de Eva, a raça dos homens,

Cujo sangue a Palavra encerra.

Desde os primórdios possuem todos

O dom de as coisas nomear.

E à imperatriz Criança, em tempos outros,

Podiam eles vida e nome dar.

E davam-Ihe lindos nomes,

Mas há muito tempo atrás,

Pois vinham à fantasia os homens,

E o caminho não sabem mais.

Esqueceram-se de que existimos

Em nós deixaram de crer.

De lá viesse um ser pequenino,

Para nosso problema, então, resolver!

Acreditasse um deles, apenas um só,

E ouvisse nosso chamar!

P'ra eles é fácil. Difícil é p'ra nós,

Muito difícil de até eles chegar.

Maya Moldes; Mestranda no Programa de Pós-Graduação em História na Universidade Federal do Estado do Rio de Janeiro (PPGH - UNIRIO); Brasileira; reside em Rio de Janeiro - RJ; email: maya.moldes.mrp@gmail.com 


\author{
Pois do outro lado fica seu mundo, \\ E até lá não podemos chegar. \\ O que te fala Uiulala, guarda bem fundo, \\ Jovem herói, não te esquecerás? (ENDE, 1986, 99-100).
}

Alguns versos são cruciais para nosso entendimento: "Da história figura e sonho/ É tudo o que somos, o que de ser precisamos. /Não podemos, portanto, criar algo novo/ Sábio, Criança ou Rei que sejamos." (ENDE, 1986, 99). A personagem admite se tratar disso, de uma personagem. Todas elas, assim como o reino, são resultados da imaginação humana, portanto, não podem salvar a si mesmas. Elas cumprem um roteiro, seu destino não lhes pertence, nem mesmo ao mais corajoso dos heróis, como Atreiú. Precisam de um narrador. É ao homem que foi dada a prerrogativa de narrar, ou seja, de criar algo novo no mundo, ainda que esteja apenas recontando uma velha história. É em nosso sangue que a "Palavra" está encerrada, como fala outro dos versos ou como podemos pensar na dita linguagem adâmica. Mas, como diz Benjamin - e, nesse momento, - Ende, a arte de narrar está em vias de extinção. O narrador: “(...) é para nós algo de distante, e que se distancia cada vez mais."(BENJAMIN, 2012, 213); por isso Fantasia está morrendo.

III

Finalmente, o prometido final feliz. Depois das muitas aventuras de Atreiú, que possuíam o fito único de atrair Bastian para a história (embora nenhum dos dois o soubesse), nosso menino no sótão sabe tão bem quanto nós como salvar Fantasia: basta dar um novo nome para a imperatriz Criança. Depois de justas hesitações, ele finalmente o pronuncia: "Filha da Lua, Filha da Lua! Aqui vou eu, Filha da Lua! Em breve estarei aí." (ENDE, 1986, 177).

Nesse ponto era de se imaginar que o livro estivesse próximo de sua última página, o que não é o caso. Isso porque as aventuras de Bastian no reino são muitas e significativas. Quando ele chega à história sem fim e encontra a imperatriz Criança, o nada já havia feito seu estrago. Por isso a menina lhe dá uma semente que restou de seu antigo império e diz: "- Fantasia vai renascer 
de seus desejos, Bastian." (ENDE, 1986, 177). Já comentamos sobre a natureza germinativa das verdadeiras narrativas, o que literalmente acontece a seguir:

\begin{abstract}
A semente germinava muito depressa, tão depressa que era possível vê-la crescer. Lançou folhas e caules, formou botões, que desabrocharam em flores coloridas de cores variadas e brilhantes, fosforescentes. Depois formaram-se pequenos frutos, que explodiam como fogos de artifício em miniatura, assim que estavam maduros, produzindo uma chuva de novas sementes faiscantes, que também começavam a germinar. (ENDE, 1986, 179).
\end{abstract}

Bastian se torna o narrador. Em Witte: "O poeta é o 'princípio da forma', princípio que é fundador da unidade e que mantém unido o mundo desintegrado. Na medida em que ele dá forma ao povo e aos deuses, também dá 'formaa si próprio"'. (WITTE, 2017, 30). Aos poucos, conforme narra novas aventuras para o reino, Bastian conta histórias também sobre si mesmo e a criança gorda e desajeitada vai tomando uma aparência mais velha, mais alta e mais distinta como um herói - e emsua memória as lembranças de um dia não ter tido figura tão bela e valente e de ter sofrido perseguições por seu jeito introvertido vão se esvaindo... Se é importante ressaltar este aspecto, é porque ele recai em uma nova problemática: Bastian não esboça interesse em voltar ao mundo real. Nesse caso, seria questão de tempo até Fantasia tornar a adoecer, pois o que o reino precisa é da transmissão de experiências, para retomarmos Benjamin, não de um redentor. É, portanto, necessário que o menino volte, conte sua história a outrem e assim por diante, garantindo o fluxo entre os dois mundos.

Em resumo, Bastian tanto narra que se esquece de quem ele foi outrora. Cada história lhe custa uma lembrança e essas devem se esgotar em algum momento. Nossa conclusão é a seguinte: as narrativas são tecidas na substância da "vida vivida" (BENJAMIN, 2012, 217), ou seja, as experiências. Por isso os seres fantásticos não podem narrar, porque eles não vivem experiências, apenas aventuras, como a personagem épica: "Ulisses é, quando regressa, exatamente o mesmo que abandonara Ítaca duas décadas atrás." (AUERBACH, 2013, 14). Bastian é humano, portanto cresce e se modifica e acumula vivências de onde extrai suas histórias. Acontece que ao entrar em Fantasia e tornar-se menos criança e mais herói ele se paralisa nessa posição temporal mística que o impede de constituir novas experiências, apenas faz gastar as que possui. Sua perda de memória, podemos supor, é que ambas (recordação e experiência) estão Maya Moldes; Mestranda no Programa de Pós-Graduação em História na Universidade Federal do Estado do Rio de Janeiro (PPGH - UNIRIO); Brasileira; reside em Rio de Janeiro - RJ; email: maya.moldes.mrp@gmail.com 
intimamente ligadas, pois a segunda se acessa através da primeira: "A memória é a faculdade épica por excelência." (BENJAMIN, 2012, 227). O caso-limite é quando Bastian chega ao ponto de esquecer o próprio nome. O seu árduo caminho de volta é de onde iremos extrair as esperadas possibilidades de um final feliz para o narrador.

Há dois episódios cruciais até seu regresso: o retorno à infância e à memória perdida. Após muito vagar como um ninguém, Bastian finalmente chega a um lugar chamado Casa Mutante, onde todos os cômodos e móveis são tão grandes, que ele volta a se sentir como uma criança pequena. Na casa há a dama Aiuola, uma árvore com forte instinto maternal, que lhe trata como a um pequenino. Levantamos a hipótese de que nosso protagonista tornou-se mais herói e menos menino, perdendo com isso a capacidade de mudar; não por coincidência a casa se chama Mutante, pois não só seus aposentos são esquisitos, como seus habitantes, atendendo a esse convite à infância, retomam aos poucos essa capacidade de modificar-se. Tornar à infância.

Diz Agamben, em seu livro "Infância e História, Destruição da experiência e origem da História":

\begin{abstract}
A in-fância que está em questão no livro não é simplesmente um fato do qual seria possível isolar um lugar cronológico, nem algo como uma idade ou um estado psicossomático que uma psicologia ou uma paleoantropologia poderiam jamais construir como um fato humano independente da linguagem. (AGAMBEN, 2005, 10).
\end{abstract}

É claro que a infância de Bastian é literal, pois é assim que as coisas se dão em Fantasia. Mas podemos arriscar ampliar essa conclusão, a partir da tese de Agamben. Infância, cuja etimologia remete à negação da voz, "sem voz", é a hipótese do autor para se pensar a questão da linguagem e da experiência (bem como uma relação entre ambas). Contrapondo Heidegger, que fala em fazer uma experiência com a linguagem, lá onde ela falta, pois na ausência que a língua indica o que ela pressupõe, Agamben diz que: "A aposta da infância é que, ao contrário, seja possível uma experiência da linguagem que não seja simplesmente sigética ou uma insuficiência dos nomes." (AGAMBEN, 2005, 13). Ao invés disso, ele diz: "Um experimentum linguae deste tipo é a infância, na qual os limites da linguagem não são buscados fora da linguagem, na direção de 
sua referência, mas em uma experiência da linguagem como tal, na sua pura auto referencialidade." (AGAMBEN, 2005, 12). Como dá a compreender: é onde há ou parece haver o inefável, que alguma voz reside.

O segundo episódio se dá quando Bastian, após vagar mais um tanto, encontra-se em uma paisagem coberta por neve, diante de uma mina e de uma choupana, onde vive o mineiro cego Yor.Sobre a neve havia imagens, como vitrais, que representavam todo tipo de cenas: "Havia figuras disfarçadas que pareciam flutuar num grande ninho de pássaros, burros com togas de juízes, relógios que se fundiam como queijos cremosos, ou ainda marionetes em praças iluminadas onde não havia ninguém." (ENDE, 1986, 368). E, sobre seu material: "Eram placas muito finas de uma espécie de mica transparente e colorida, de todas as formas e tamanhos, quadradas e redondas, fragmentadas ou inteiras." (ENDE, 1986, 368). O mineiro nos presta mais esclarecimentos sobre elas:

- São os sonhos esquecidos do mundo dos homens, explicou Yor. Depois de ter sido sonhado, um sonho não pode desaparecer. Mas quando o homem que o sonhou o esquece, para onde vai? Vem para cá, para junto de nós, em Fantasia, e fica enterrado nas profundezas da terra. É ali que estão os sonhos esquecidos, em camadas muito finas dispostas umas sobre as outras. Quanto mais fundo se cava, mais espessa são essas camadas. Todo o reino de Fantasia assenta-se sobre alicerces de sonhos esquecidos. (ENDE, 1986, 369).

O trabalho de Yor consiste em, com toda delicadeza e precisão, escavar essas imagens encrustadas na mina e ensina este ofício a Bastian, para que o menino (já é novamente um menino) encontre um sonho seu: "Neste primeiro dia e também nos seguintes, guiando-Ihe as mãos em silencio, o mineiro ensinou Bastian a arte de separar umas das outras as finas camadas de mica e de levantá-las cuidadosamente." (ENDE, 1986: 371). É um ofício extremamente tedioso, realizado no breu e calor da mina, dia após dia. Benjamin nos diz sobre o narrador e sua relação com a narrativa:

Esse processo de assimilação se dá em camadas muito profundas e exige um estado de distensão cada vez mais raro. Se o sono é o ponto mais alto da distensão física, o tédio é o ponto mais alto da distensão psíquica. O tédio é o pássaro onírico que choca os ovos da experiência. O menor sussurro nas folhagens o assusta. (BENJAMIN, 2012, 221).

Não à toa é o alerta de Yor: “- Mas não diga nada, não faça barulho, ouviu? O que você vai ver é o meu trabalho de muitos anos. O menor ruído pode 
destruí-lo. Por isso, fique calado e ande com cuidado." (ENDE, 1986, 368). Por isso, mais um passo para o caminho de casa se desvia por essas camadas muito profundas da mina, onde ele se encontra extremamente entediado e sem emitir um ruído que seja, para não destruir os vitrais de sonhos, ou, também é possível dizer, não assustar o pássaro onírico que choca os ovos da experiência. Bastian desempenha uma tarefa artesanal, termo que já vimos o quão importante é ao narrador, graças ao conhecimento que lhe foi transmitido por um mestre em seu ofício, outra questão também essencial. E cultivando “(...) esse procedimento paciente da natureza" (VALERY, 1960 apud BENJAMIN, 2012, 222), o menino encontra seu sonho, aquele que o conduz para casa.

Que final feliz podemos oferecer ao Narrador? Em certo momento, quando Fantasia está quase toda consumida pelo nada, Atreiú se encontra com a imperatriz Criança e lamenta ter falhado em sua missão, pois Bastian ainda não havia adentrado na história e nem ele sabia que esse momento estava próximo. Ela Ihe tranquiliza:

- Isso quer dizer que a senhora há muito tempo já sabia da mensagem que eu Ihe traria. Aquilo que a velha Morla me disse no Pântano da Tristeza, o que a voz misteriosa de Uiulala me revelou - já sabia de tudo isso?

- Sim, disse ela, e já o sabia antes mesmo de enviá-lo para a Grande Busca.

Atreiú engoliu em seco.

- Mas então, perguntou ele finalmente, por que me enviou? O que esperava que eu fizesse?

- Aquilo que você fez, respondeu ela.

- O que eu fiz... repetiu Atreiú devagar, e formou-se uma funda ruga de cólera entre suas sobrancelhas. Mas, se é como a senhora diz, então foi tudo desnecessário. Não era preciso me mandar para a Grande Busca. Já ouvi dizer que suas decisões são muitas vezes incompreensíveis para nós. Mas depois de tudo que passei é difícil suportar com paciência a ideia de que a senhora estava brincando comigo.

Os olhos da imperatriz Criança tornaram-se muito sérios.

- Eu não estava brincando com você, Atreiú, disse ela, e sei bem o que Ihe devo. Tudo aquilo que você passou foi necessário. Eu o enviei para a Grande Busca, não para ouvir a mensagem que você me traz agora, mas porque era a única maneira de chamar nosso Salvador. Pois ele participou de tudo que você fez, e o acompanhou em sua longa viagem.

(...) E também agora escuta cada palavra que dizemos. E sabe que

Maya Moldes; Mestranda no Programa de Pós-Graduação em História na Universidade Federal do Estado do Rio de Janeiro (PPGH - UNIRIO); Brasileira; reside em Rio de Janeiro - RJ; email: maya.moldes.mrp@gmail.com 
estamos falando dele, que o aguardamos e depositamos nele nossas esperanças. Talvez perceba agora que todos os grandes trabalhos que você realizou, Atreiú, foram feitor por ele, que toda Fantasia o chama! (ENDE, 1986, 152,153).

Para além das necessárias reflexões sobre a infância, a experiência e a memória, esse é o final feliz que o artigo espera trazer: um convite. Adotamos estratégia similar a da imperatriz Criança e esperamos que seja perdoada, mas, assumindo novamente a verdadeira narrativa como uma semente capaz de germinar, nosso desfecho é humilde: espera tê-la germinado no presente texto e semeado essa vontade em outrem, após narrar tantas aventuras. Pois aprendemos com Bastian que o declínio da narrativa não precisa de um herói, assim como também sabemos que aquela forma de experiência coletiva, Erfahrung, não irá retornar. Resta-nos, então, num apelo muito benjaminiano, cultivar essas sementes conforme pudermos.

\section{REFERENCIAS}

ADORNO, Theodor W. Notas de Literatura I. São Paulo: Duas Cidades, Editora 34, 2003.

AGAMBEN, Giorgio. Infância e História - Destruição da experiência e origem da história. Minas Gerais: Editora UFMG, 2005.

ARENDT, Hannah. Walter Benjamin $(1892-1940)$. In_: Homens em tempos sombrios. São Paulo: Companhia das Letras, 2008.

AUERBACH, Erich. Mimesis. São Paulo: Editora Perspectiva, 2013.

BENJAMIN, Walter. Reflexões sobre a criança, o brinquedo e a educação. São Paulo: Duas Cidades, Editora 34, 2009. . O Narrador - considerações sobre a obra de Nicolai Leskov. In__: Obras Escolhidas, vol. 1. Magia e Técnica, Arte e Política. . Origem do drama trágico alemão. Belo Horizonte: Autêntica, 2011. 
. Obras Escolhidas, vol. 1. Magia e Técnica, Arte e Política. Ensaios

sobre Literatura e História da Cultura. São Paulo: Brasiliense, 2012.

. Obras Escolhidas, vol. 2. Rua de mão única. São Paulo: Brasiliense, 2012.

CANHOTO, Vinicius. Teoria da Literatura e o problema do Narrador e Narração: um debate entre Benjamin, Lukács e Adorno. In__:. Cadernos Walter Benjamin 18, 2017: 89,111.

ECO, Umberto. Seis passeios pelos bosques da ficção. São Paulo: Companhia das Letras, 2004.

Ensaios sobre Literatura e História da Cultura. São Paulo: Brasiliense, 2012.

ENDE, Michael. A História sem Fim. São Paulo: Martins Fontes: 1986.

FREITAS, Jorge. Anotações sobre a teoria da alegoria barroca de Walter Benjamin. Belo Horizonte: Em Tese, 2014.

GAGNEBIN, Jeanne Marie. Walter Benjamin, os cacos da história. São Paulo: Editora Brasiliense, 1993.

História e narração em Walter Benjamin. São Paulo: Editora Perspectiva, 1994.

Sete aulas sobre linguagem, memória e história. Rio de Janeiro: Imago Editora, 1997.

LACAPRA, Dominick. History \& Criticism. Ithaca: Cornell University Press, 1985.

LÖWY, Michael. Aviso de Incêndio - Uma Leitura das Teses "Sobre o Conceito de História”. São Paulo: Boitempo, 2005.

LUKÁCS, Georg. A teoria do romance. São Paulo: Editora 34, 2009.

MATOS, Olgária. A Escola de Frankfurt, Luzes e sombras do lluminismo. São Paulo: Editora Moderna, 1993.

Maya Moldes; Mestranda no Programa de Pós-Graduação em História na Universidade Federal do Estado do Rio de Janeiro (PPGH - UNIRIO); Brasileira; reside em Rio de Janeiro - RJ; email: maya.moldes.mrp@gmail.com 